\title{
Седьмые международные чтения памяти В.М. Пескова (к 90-летию со дня рождения)
}

\author{
А. В. Телегина, В. В. Свиридов $\bowtie$ \\ Воронежский государственный университет, Российская Федерация \\ (394018, г. Воронеж, Университетская пл., 1)
}

\begin{abstract}
Аннотация: Рассматривается положительный опыт проведения чтений и международной конференции, посвященной 90-летию со дня рождения В. М. Пескова.

Ключевые слова: конференция, В. М. Песков, журналист, писатель, эколог.

Для цитирования: Телегина А.В., Свиридов В.В. Седьмые международные чтения памяти В. М. Пескова (к 90-летию со дня рождения) // Вестник Воронежского государственного университета. Серия География. Геоэкология, 2020, № 3, с. 94-97. DOI: https://doi.org/10.17308/geo.2020.3/3029
\end{abstract}

14 марта 2020 года в Воронежском государственном природном биосферном заповеднике им. В. М. Пескова состоялись седьмые Песковские чтения. Они приурочены к 90-летию В. М. Пескова журналиста, эколога, географа, публициста и фотографа. Это мероприятие, ставшее доброй традицией заповедника, проходит с целью изучения творческого наследия, популяризации и увековечивания его памяти. Чтения в течение нескольких лет ставят и успешно решают задачи по выявлению направлений деятельности, обобщению и изучению образовательно-просветительских возможностей творческого наследия В. М. Пескова. В этом году в рамках традиционных Песковских чтений по предложению Воронежского отделения РГО было решено провести также научную конференцию «Журналистика и география».

Василий Михайлович Песков стал легендой еще при жизни. Он наполнял российскому (советскому) читателю смыслом такие понятия, как любовь к Отечеству, ответственность за свои собственные действия и свою страну. Единственный в отечественной истории журналист - лауреат Ленинской премии за авторскую работу.

Василий Песков родился 14 марта 1930 года в селе Орлово Новоусманского района Воронежской области. После окончания средней школы и шко- лы киномехаников работал пионерским вожатым, помощником фотографа. С 1953 года работал в воронежской областной молодежной газете «Молодой коммунар». В 1956 году после публикации очерка «Когда бушевали метели» его приглашают в газету «Комсомольская правда», в которой работал 57 лет.

В. Песков - основоположник жанра экологической и космической журналистики. Его персональная рубрика «Окно в природу» выходила на страницах «Комсомольской правды» более 40 лет. Этот факт зафиксирован в книге рекордов Гиннесса. Василий Песков брал первое интервью на Земле у первого космонавта Юрия Гагарина и у всех космонавтов первого отряда. В. Песков много писал о войне. Он брал интервью у маршалов Советского Союза Г.К. Жукова и А. М. Василевского. В. М. Песков - автор всемирно известной повести «Таежный тупик» о семействе отшельников Лыковых, спрятавшихся в глухой тайге. В. М. Песков - известный фотограф; член жюри конкурса «3олотая черепаха», один из основателей жанра фотоновеллы в журналистике. В. М. Песков - известный путешественник, почетный член РГО. Он побывал на всех континентах, кроме Южной Америки, а также на обоих полюсах Земли. С 1975 по 1990 год В. М. Песков вел телепередачу «В мире

(C) Телегина А.В., Свиридов В.В., 2020

С Свиридов Вадим Васильевич, e-mail: vrn-rgo@bk.ru

Контент доступен под лицензией Creative Commons Attribution 4.0 License. 
животных». В. М. Песков - Почетный гражданин города Воронежа. Ушел из жизни 12 августа 2013 года в Москве.

В 2013 году в Воронежском государственном заповеднике был открыт единственный в России мемориальный музей Василия Михайловича Пескова. С 2014 года в заповеднике ежегодно проходят памятные мероприятия - Песковские чтения и День памяти Василия Пескова.

Седьмые Песковские чтения были подготовлены и проведены Н.Ю. Хлызовой - основателем и хранителем музея В. М. Пескова.

В программе седьмых Песковских чтений прошла презентация выставки «Река жизни». Путешествием по реке жизни Василий Михайлович называл воспоминаниями.

В музее журналиста в визит-центре гостям представили три интерактивные выставки «Творческий плацдарм», «Речка моего детства», «Бессмертный полк Василия Пескова» (о Великой Отечественной войне). Также участники могли изучить экспозиции «Речка моего детства», «Отечество», «Окно в природу», «Любовь фотография», выставки «Дорогою добра» и «Любимая птица Василия Пескова».

Свои работы и исследования представили учащиеся Тресвятской и Орловской школ, ученые, друзья и коллеги журналиста подготовили воспоминания и доклады, посвященные жизни и творчеству нашего талантливого земляка.

Мероприятие открыл директор заповедника А. А. Тарасов, рассказавший о связях Василия Пескова с особо охраняемыми природными территориями. Вступительное слово на открытии Песковских чтений было у Депутата ГД РФ А.Н. Пономарева. Он проинформировал собравшихся о том, что в августе в заповеднике появится памятник писателю.

Ведущий научный сотрудник Института экологии внутренних вод РАН А. А. Прокин подчеркнул, что такое отношение у Василия Михайловича к своей малой родине выработалось неспроста - в этих лесах сохранилось уникальное разнообразие животного и растительного мира - встречаются выхухоль, бобры, можно найти даже клюкву. А в реке Усмань водятся более 60 видов уникальных беспозвоночных. В свое время именно Василий Михайлович отстоял этот и другие заповедники, которые хотели сделать национальными парками. Директор Института А.В. Крылов подчеркнул, что своим творчеством Песков в России обратил внимание на судьбу малых рек. И сам
А. В. Крылов выбрал профессию биолога благодаря передаче «В мире животных» с участием В. М. Пескова.

Фильм-воспоминание о Василии Михайловиче подготовили журналисты «Комсомолки». Для них он был и остается человеком, открывшим окно в природу, Учителем, примером, как нужно любить свою Родину.

На Песковских чтениях Н.Ю. Хлызова представила поэта (студента факультета географии, геоэкологии и туризма ВГУ) Василия Нацентова с интереснейшим эссе: «Путешествие с молодым месяцем, или журналистика как фантастика» (развернутое стихотворение в прозе с вынужденными объяснениями).

Магистр факультета географии, геоэкологии и туризма Воронежского государственного университета Анна Телегина рассказала о роли В.М. Пескова в ее жизни, в ее научных работах.

На мероприятии выступили школьники, прочитали стихотворение о жизни Василия Пескова, рассказали как занимаются краеведением по авторской программе «Уроки доброты деда Василия».

Известный воронежский писатель Виктор Будаков вспомнил о работе В.М. Пескова в газете «Молодой коммунар», в редакции которой начали свой творческий путь многие известные журналисты и писатели, о его удивительном чувстве скромности, о том, что Песков был великим фотохудожником. Он прекрасно чувствовал куда движется мир, и что сейчас все бы сказали ему великое спасибо, которое идет из глубин русского народа.

Впервые мероприятие приобрело международный характер. О жизни В.М. Пескова рассказал его друг - французский писатель, переводчик Ив Готье. Ив перевел на французский язык «Таежный тупик- Пескова. Так Франция, а затем и другие страны узнали об отшельнице Агафье Лыковой. Ив Готье признался, что ему очень не хватает Василия Михайловича. Все это он рассказал в видеопослании, которое отправил накануне чтений. Изза коронавируса приехать в Россию переводчик, к сожалению, не смог.

Во второй части Чтений перед гостями показали два фильма представителей Алтайского заповедника - Надежды и Сергея Усик «Привет из Таежного тупика», где были представлены ландшафты заповедника и отношения В. М. Пескова с Агафьей Лыковой.

Творческому наследию В.М. Пескова и деятельности ВГУ по просвещению и образованию 
студентов и школьников посвятил свое выступление заместитель декана факультета географии, геоэкологии и туризма Воронежского государственного университета, секретарь Совета Воронежского отделения Русского географического общества В. В. Свиридов.

Также перед гостями выступили С. И. Жданов (фотохудожник и друг В. М. Пескова из Оренбурга), В.Р. Хилтунен (рассказал о дружбе и интервью В. М. Пескова), В.М. Баранов (художник из г. Семилук, подарил музею свою авторскую картину), М.Н. Шашкина (работник государственного архива Саратовской области), М.М. Кривошлыков (редактор Богучарской районной газеты, подарил личные фото с В.М. Песковым, рассказал о встрече В. М. Пескова и М.А. Шолохова) и другие участники.

Было много желающих рассказать о В. М. Пескове, почти каждому из собравшихся есть что вспомнить о нем, но надеемся, что новые истории мы услышим на следующих мероприятиях - Дне памяти и Восьмых Песковских чтениях. На мероприятии было объявлено о проведении Всероссийской научно-практической конференции «Журналистика и география» в ВГУ. В заключение чтений для его участников была проведена экскурсия по территории Воронежского заповедника.

Всероссийская научно-практическая конференция с международным участием «Журналистика и география», посвященная 90-летию Василия Михайловича Пескова, состоялась в заочной форме 20 марта 2020 года. Организаторы Конференции Федеральное государственное бюджетное образовательное учреждение высшего образования «Воронежский государственный университет» в лице факультетов журналистики и географии, геоэкологии и туризма, Федеральное государственное бюджетное учреждение «Воронежский государственный природный биосферный заповедник», Всероссийская общественная организация «Русское географическое общество». Информационную поддержку осуществляла газета «Комсомольская правда в Воронеже».

В Конференции приняли участие журналисты, географы, экологи, краеведы, культурологи, археологи, этнографы, специалисты музейного дела не только регионального, но и федерального уровня (Москва, Санкт-Петербург, Астрахань, Белгород, Владивосток, Иркутск, Курск, Рязань, Тамбов, Тула, Якутск и др. - всего 28 регионов России), а также представители научных сообществ Армении, Беларуси, Украины, Приднестровья.
Работа Конференции осуществлялась по направлениям, которые подчеркивают разносторонний характер и многогранность личности Василия Михайловича Пескова: 1. Человек и природа в отечественной публицистике. 2. Образы природы в фотографии, живописи и графике. 3. Ландшафтоведение: художественное и эстетическое восприятие ландшафта. 4. Охрана окружающей среды и заповедное дело. 5. Страноведение. 6. Краеведение. 7. Социально-экономические аспекты развития регионов. 8. Культурно-историческое наследие регионов. 9. Экологический туризм.

Конференция показала, что произведения В. М. Пескова, на которых воспитаны три поколения граждан нашей страны, по-прежнему остаются ценнейшим материалом для экологического, нравственного, эстетического воспитания и образования подрастающего поколения. Материалы, представленные участниками конференции, раскрывают новые штрихи жизни и деятельности В. М. Пескова. По итогам работы был подготовлен сборник материалов в двух томах, которые были изданы к Дню памяти Василия Пескова.

Участники считают целесообразным организовать проведение Конференции, совмещенной с Песковскими чтениями, на постоянной основе один раз в два года.

Участники конференции и Совет Воронежского отделения РГО считают возможным ходатайствовать перед Ученым Советом и Съездом Русского географического общества об учреждении медали РГО имени В. М. Пескова по направлениям «Экологическая журналистика» и «Экологическое воспитание и образование».

Русское географическое общество в ознаменование своего юбилея приняло решение об увековечивании памяти выдающихся географов, ученых и общественных деятелей, внесших значительный вклад в развитие нашего Отечества, его научного и культурного достояния. В этой связи подготовлены специальные памятные таблички, которые будут установлены на объектах, связанных с их жизнью и деятельностью. В нашем регионе один из первых таких знаков, увековечивающий память Василия Пескова, в ближайшее время будет установлен на территории Воронежского государственного природного биосферного заповедника, который по праву носит его имя.

Конфликт интересов: Авторы декларируют отсутствие явных и потенциальных конфликтов интересов, связанных с публикацией настоящей статьи.

Поступила в редакичюю 07.06.2020

Принята к публикации 26.07.2020 


\title{
The Seventh International Readings Dedicated to the Memory of V.M. Peskov (for the 90th anniversary of his birth)
}

\author{
A. V. Telegina, V. V. Sviridov $\bowtie$ \\ Voronezh state University, Russian Federation \\ (1, Universitetskaya pl., Voronezh, 394018)
}

\begin{abstract}
The article is devoted to the positive experience of holding the Seventh Readings and the International conference dedicated to the 90th anniversary of the birth of V.M. Peskov.

Key words: conference, V. M. Peskov, journalist, writer, ecologist.

For citation: Telegina A. V., Sviridov V. V. The Seventh International Readings dedicated to the memory of V. M. Peskov (for the 90th anniversary of his birth). Vestnik Voronezskogo gosudarstvennogo universiteta. Geografia geoekologia, 2020, No. 3, pp. 94-97. (In Russ.) DOI: https://doi.org/10.17308/geo.2020.3/3029

Conflict of interests: The authors declare no information of obvious and potential conflicts of interest related to the publication of this article.
\end{abstract}

Received: 07.06.2020

Accepted: 26.07.2020

Телегина Анна Вячеславовна

магистр кафедры физической географии и оптимизации ландшафта факультета географии, геоэкологии и туризма Воронежского государственного университета, г. Воронеж, Российская Федерация, e-mail: tav.vrn@mail.ru

Свиридов Вадим Васильевич

старший преподаватель кафедры физической географии и оптимизации ландшафта факультета географии, геоэкологии и туризма Воронежского государственного университета, г. Воронеж, Российская Федерация, ORCID: https://orcid.org/0000-0002-0614-1248, e-mail: vrn-rgo@bk.ru
Anna V. Telegina

Undergraduate of the Department of Physical Geography and Landscape Optimization, Faculty of Geography, Geoecology and Tourism, Voronezh State University, Voronezh, Russian Federation, e-mail: tav.vrn@mail.ru

Vadim V. Sviridov

Senior Lecturer of the Department of Physical Geography and Landscape Optimization, Faculty of Geography, Geoecology and Tourism, Voronezh State University, Voronezh, Russian Federation, ORCID: https://orcid.org/0000-0002-0614-1248, e-mail: vrn-rgo@bk.ru

(C) Telegina A. V., Sviridov V.V., 2020

\Vadim V. Sviridov, e-mail: vrn-rgo@bk.ru

(c) (i) The content is available under Creative Commons Attribution 4.0 License. 